\title{
ДИЗАЙН
}

УДК: 7.012-028.22:[659.125:159.937

Божко Тетяна Олександрівна, кандидат мистецтвознавства, Київський національний університет культури і мистецтвв, вул. С. Коновальия,36, Київ, Україна, 01133, https://orcid.org/0000-0001-5696-1941, bozfhko_to@ukr.net

\section{КОМПОЗИЦІЯ ЯК ЧИННИК ХУДОЖНЬОЇ ВИРАЗНОСТІ ТВОРІВ ГРАФІЧНОГО ДИЗАЙНУ}

Мета - дослідити вплив композиції на змістове наповнення й декодування візуальних повідомлень. Методологія дослідження - в досліджені впроваджені метод теоретичного та структурно-семіотичного аналізу. Завдяки схематизації інформаційно-змістових елементів доведено вплив композиції на швидкість та точність декодування інформації; висвітлено залежність декодування змісту від різних способів композиційної організації. Наукова новизна полягає у виявленні залежності змістового декодування відносно нейтральних комунікативних елементів від способів їх композиційної організації та у виявленні ролі композиції в формуванні візуально-стилістичної єдності носіїв фірмового стилю. Встановлено, що спосіб кодування інформації на основі асоціативного варіювання властивостями геометричних примітивів, або наближених до них форм призводить до формування логіки сприйняття знаків - образологіки, що дозволяє співвідносити схематизовані площинні зображення 3 об'єктами, процесами та явищами навколишнього світу. Закономірності такої образологіки співвіднесено з принципами гештальду, сформованими в психологічній галузі. Висновки. Зміст візуальних повідомлень сприймається як відповідність цілісності образної побудови інформаційної структури до сутності візуально кодованих зображень. Також постає значущість композиційної структури як цілісності, здатної набувати синергічних ознак й передавати інформацію значно більшу, ніж сукупність окремо взятих елементів. Дієвість механізмів «переробки» значної кількості образного, змістового та емоційного матеріалу в набор стереотипних уявлень, що активно продукуються i споживаються масовою культурою, забезпечується завдяки схематизації $\mathrm{i}$ дотримання умов композиційного представлення інформаційних кодів, дієвість впливу яких $є$ подібною до творів образотворчого мистецтва. Утримання принципів композиційної організації інформації, висвітлених у даній публікації, забезпечує єднання ідеї та форм ії̈ графічного втілення.

Ключові слова: композиційна організація; комунікативні елементи; рекламнографічна продукція.

Божко Татьяна Александровна, кандидат искусствоведения, Киевский нацииональный университет культуры и искусств, ул. Е. Коновальца, 36, Киев, Украина

\section{Композиция как фактор художественной выразительности произведений графического дизайна}

Цель - проследить влияние композиции на содержательное наполнение и декодирование визуальных сообщений. Методология исследования - в исследовании использованы метод теоретического и структурно-семиотического анализа. Благодаря схематизации информационно-содержательных элементов доказано влияние композиции на скорость и точность декодирования информации; освещена зависимость декодирования содержания от различных способов композиционной организации. Научная новизна состоит в выявлении зависимости содержательного декодирования относительно нейтральних комуникативных элементов от способов их композиционной организации и в выявлении роли композиции в формировании визуально-стилистического единства 
носителей фирменного стиля. Установлено, что способ кодирования информации на основе асоциативного варьирования свойствами геометрических примитивов, или приближенных к ним форм, приводит к формированию логики восприятия знаков - образологики, что позволяет соотносить схематизированные плоскостные изображения с объектами, процесами и явлениями окружающего мира. Закономерности такой образологики соотнесены с принципами гештальда, сформированными в психологической отрясли научных знаний. Выводы. Содержание визуальных сообщений воспринимается как соответствие целостности образного построения информационной структуры к сущности визуально кодированных изображений. Также становятся наглядным значение композиционной структуры, как целостности, способной приобретать признаки синергичности и передавать информацию значительно большую, чем совокупность отдельно взятых элементов. Действенность механизмов «переработки» значительного количества образного, содержательного и емоционального материала в набор стереотипних представлений, которые активно продуцируются и потребляються массовой культурой, обеспечивается благодаря схематизации елементов и удержании условий композиционного представления информационных кодов, действенность влияния которых является подобной произведениям изобразительного искусства. Удержание принципов композиционной организации информации, освещенное в данной публикации, обеспечивает слияние идеи и форм ее графического воплощения

Ключевые слова: композиционная организация; коммуникативные элементы; рекламно-графическая продукция.

Bozhko Tetiana, PhD in Art Criticism,, Kyiv National University of Culture and Arts, 36, Y. Konovaltsia St, Kyiv, Ukraine

Composition as a factor of artistic expression in graphic design works

The purpose of the article is to investigate the influence of composition on the content and decoding of visual messages. The research methodology consisted in the method of theoretical and structural-semiotic analysis. Through schematization of informational and content-related elements, the influence of composition on the speed and accuracy of decoding information is proved; the dependence of content decoding on different ways of compositional organization is highlighted. The scientific novelty of the work lies in revealing the dependence of content decoding regarding neutral communicative elements on the methods of their compositional organization and outlining the role of composition in the formation of the visual-stylistic unity of carriers of the original style. It was established that the method of encoding information on the basis of associative variation of the characteristics of geometric primitives, or forms that are similar to them, leads to the formation of the logic of perception of signs - the logic of images, which allows for the correlation of schematized plane images with objects, processes and phenomena of the outside world. The rules of this logic of images were brought into correlation with the principles of Gestalt, which were formed in psychology. Conclusions. The content of visual messages is perceived as the correspondence of the integrity of the figurative construction of the informational structure to the essence of visually encoded images. It also shows the significance of the compositional structure as a unity capable of obtaining synergistic features and transmitting information much larger than the set of individual elements. The effectiveness of the mechanisms of "processing" a significant amount of figurative, substantive and emotional material into a set of stereotypical representations that are actively produced and consumed by mass culture is ensured by the schematization and compliance with conditions of the compositional representation of information codes, the effectiveness of which is similar to the works of fine arts. Maintaining the principles of compositional organization of the information covered in this publication ensures the unification of ideas and forms of its graphic embodiment. products.

Key words: compositional organization, communicative elements, advertising and graphic

Вступ. Графічний дизайн є діяльністю, яка зорієнтована на візуальне втілення інформації та ії закріплення у широкому спектрі носіїв рекламних або соціальних звернень. Проте, постійне збільшення обсягів інформації та розвиток технологій іï поширення у суспільстві потребує посилення ефективності та дієвості інформаційного впливу. Проектування візуальних 
комунікацій належить до сфери графічного дизайну, вимагає швидкого та якісного кодування змісту у візуальні структури, що повинні миттєво й точно декодуватись споживачами й впливати на них, крім інформаційного, ще й емоційно-образне враження, що посилює впливовість отриманої інформації.

Однак, на практиці забезпеченню встановлених вимог суттєво перешкоджає все ще недостатньо розбудована науково-методична база, зокрема, з графічного дизайну, в якій наявні лакуни щодо, безпосередньо, способів посилення ефективності впливу інформації, яка подається, і їх залежності від композиційної організації.

Позбавлений чітко визначених орієнтирів, проектувальник опиняється в ситуації, в якій він навмання, користуючись переважно власним досвідом та інтуїцією, намагається співвіднести необхідний для відтворення зміст інформаційного повідомлення 3 усіма існуючими засобами образного впливу, властивостями елементів графічної мови та віднайти необхідні й найбільш вдалі умови їх композиційної організації. У цьому процесі, намагаючись забезпечити інноваційну форму представлення, проектувальники найчастіше втрачають головний вектор змістоутворення, забезпечити який мали б знання щодо впливу композиційної організації на характер сприйняття інформації.

Постановка проблеми. Для усунення визначеного дисбалансу наукових знань й практичних проблем інформаційно-графічного проектування є доцільним продовжити розвідку щодо значення композиційної організації інформації для побудови ефективної рекламнографічної продукції. Сутність наукової проблеми складає визначення закономірностей образного й логічного трактування інформації, побудованої 3 абстрактних та символічних форм елементів, що володіють значним потенціалом змістового декодування. Встановлення тих умов, за яких інформаційні повідомлення можуть набувати візуально-стилістичної єдності, точності та однозначності сприйняття. Науковий інтерес також становить питання засобів посилення впливу літерно-шрифтових повідомлень за рахунок їх композиційного поєднання з образно-кодованими елементами.

Актуальність даної публікації пов'язана зі зростаючими обсягами візуальних повідомлень, що потребують точності кодування для якісного й швидкого декодування споживачами і потребою наукового висвітлення умов та закономірностей впливу композиційної організації на візуально-інформаційні структури. Наразі нагальною потребою є співставлення принципів композиції з практикою реалізації інформаційних повідомлень, побудованих на основі знакових форм. У дослідженні вперше розглядається композиція як чинник формування візуально-стилістичної єдності носіїв фірмового стилю та як засіб утворення синергічних інформаційних структур, здатних передавати інформацію значно більшу, ніж сукупність окремо взятих елементів.

Аналіз досліджень. Допоки більшість дослідників концентрують увагу на відповідності комунікативних елементів змісту, стверджують необхідність їх мінімізації й ущільнення змісту за допомогою вилучення 3 зображувальних елементів надмірної реалістичної подібності та переведення їх до рівня символів або знаків. Такі твердження знаходимо в розвідках Ганоцької (2011); Михайленко та Яковлєва (2004); Шевченко (2004); Bertin (1983).

Найбільш наближене до тематики даної розвідки дослідження Михайленко та Яковлєва (2004), результати якого викладені в навчальному посібнику, де наголошено на геометричних засадах укладання композиції, детально розглядаються питання ролі геометрії в художньому формоутворенні, викладено принципи графічної формалізації. Значну увагу приділено використанню геометричного моделювання в дизайні сучасними засобами комп'ютерної графіки. Грунтовними є розділи «Геометричні передумови формотворення знаково-символьних об’єктів графічного дизайну», «Формування професійного мислення фахівців», де багато наочних прикладів геометричних засад композиції.

Однак, питання композиційної організації комунікативних елементів в творах графічного дизайну не є остаточно вичерпаними й потребують окремого висвітлення.

У вищенаведених роботах науковців не акцентовано увагу на тому, що комунікативні елементи, навіть точно відповідні за змістом до сутності інформаційних повідомлень, не завжди 
створюють необхідне враження на споживачів. Але в деяких випадках вони, замість запланованого позитивного, створюють відверто негативне враження, утворюють змістові контексти, здатні дезорієнтувати споживачів, або спрямувати їх уяву до асоціацій, зовсім не бажаних для проектувальників та рекламодавців, не викликають бажання запам'ятовувати або детальніше розглядати й вивчати зміст візуальних звернень. Прикметно, що в переважній більшості випадків, причини такої емоційної реакції викликані, власне композиційною організацією комунікативних елементів, тобто тією інформаційною структурою, що вибудовується або «укладається» 3 них. У вищенаведених працях науковців не приділяється уваги впливу принципів композиційної організації на забезпечення візуально-стилістичної єдності в носіях фірмового стилю.

Крім того в наукових працях все ще недостатньо висвітлено роль законів і принципів композиційної організації в процесах укладання інформаційних структур, побудованих 3 абстрактних та символічних форм. А відсутність навичок співвіднесення законів та закономірностей композиційної організації 3 практикою укладання рекламно-графічної продукції, в якій по-різному кодується інформація у цілісні візуальні структури. Однак, значне збільшення кількості візуальних звернень, потребує й оновлення теоретичних поглядів щодо професійних аспектів дизайн-проектування, та визначення орієнтирів для практичної композиційної побудови візуальних звернень.

Мета статті - дослідити вплив композиції на змістове наповнення й декодування візуальних звернень; розглянути композицію як найбільш сутнісний чинник художньої виразності творів графічного дизайну.

Виклад основного матеріалу. Розглядаючи графічний дизайн, як вид художньопроектної діяльності, зорієнтований на раціональне використання зображувальних засобів у створенні візуальних комунікацій, процес проектування рекламно-графічної продукції має сприйматись як оптимізація комплексного впливу образних якостей зображувальних елементів за допомогою композиції. Отримуємо нагоду стверджувати, що у графічному дизайні, композиція бере на себе функції «змістового каркасу», подібного до каркасу споруд в архітектурному проектуванні, здатного миттєво засвідчити відповідність графічних звернень змісту, а отже й функціональному призначенню.

Одразу зауважимо, що в даній публікації будемо розглядати тільки закономірності композиційної організації елементів в «двовимірному просторі», не торкаючись питання створення ілюзорно тривимірного простору. При цьому елементи, що розглядаються, будуть наближені до ступеню знакових.

Створюючи рекламно-графічну продукцію, проектувальник змушений здійснювати вибір елементів, які необхідні для точного відтворення змісту та створити з них певну цілісність інформаційну структуру. Однак самі елементи мають бути максимально спрощені та узагальнені. Має бути відкинуте все зайве та вони мають бути зведені до рівні графічної схеми. Зважимо, що така цілісність (тобто спосіб взаємодії елементів на площині), може набувати самодостатнього значення, що спостерігаємо з прикладів (рис .1.а, б, в.).

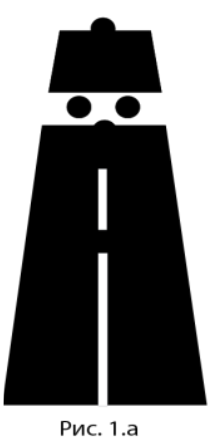

Рис. 1.a

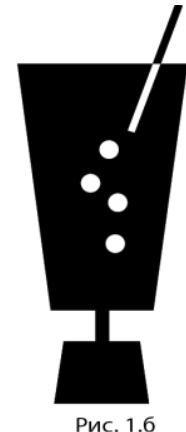

Рис. 1.6

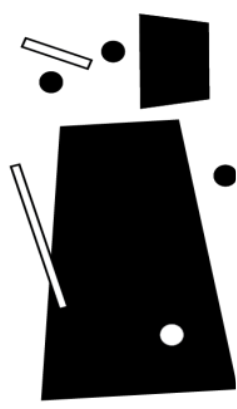

Рис. 1.в

Рисунок 1. Різні композиційні угрупування з подібних елементів Figure 1. Various compositional groups of similar elements 
Так, зображення на рис 1.а наша свідомість, мабуть, декодує як людину у плащі й шапці; зображення, подане на рис 1.6 буде співвіднесене 3 наповненим фужером. А от зображення на рис. 1.в свідомість, позбавлена можливості співвіднесення з об'єктами або подіями матеріального світу, мабуть, просто проігнорує, або сприйматиме як процес руйнації.

Розглянутий приклад свідчить про здатність нашої свідомості миттєво співвідносити отриману візуальну інформацію 3 об'єктами та процесами навколишнього світу, виокремлюючи їх найбільш сутнісні ознаки та співвідносячи їх з отриманими візуальними структурами, навіть найбільш узагальненими. У такий спосіб унаочнюється залежність між способом композиційної організації інформації та швидкістю й точністю декодування такої інформації споживачами.

Ця залежність полягає у дієвості психологічних принципів суміжності та принципу цілісності. Згідно принципу суміжності співставлення відносно нейтральних в інформаційному плані образів може викликати чітко визначені змістові асоціації. А згідно принципу цілісності всі об'єкти матеріального світу мають тенденцію до спрощення i цілісності.

Зауважимо, що самі комунікативні елементи в розглянутому прикладі були відносно нейтральні, тобто кожний 3 них не мав конкретного змістового навантаження. Вони уособлювали лише геометричні архетипи, а змістовне наповнення виникало як результат їх композиційної взаємодії.

У роботі, присвяченій дослідженню композиції плакату, Шевченко (2004, с.78-79) вказує: «... в мистецтві має право на існування не тільки принцип реалістичного відображення дійсності, де форма зображення цілком відповідає змісту, а саме зображення характеризується достовірністю i документальністю. Не менш важливим $є$ принцип асоціативного рішення теми, при якому зображення реальних чи умовних форм не має “портретної” відповідності змісту, а є лише його образним еквівалентом».

У наведеному прикладі композиційні закономірності виявились найважливішими організуючими компонентами художньої форми, а композиційне ціле створює конструктивні й смислові зв'язки. 3 цього приводу Михайленко та Яковлєв (2004, с. 56) зауважують, що «.... Елемент композиції і його ознаки є невід'ємними від фактору сприйняття. Насамперед, зв'язок між елементами означає, що навіть незначні зміни одного 3 них позначаться на іншому, чи навіть на кількох одночасно. Окремі зв'язки отримали назву композиційних засобів організації». У такий спосіб зміна композиційних зв'язків призводить або до дезорганізації, або до іншого контекстного змістового наповнення, що й спостерігали на наведеному вище прикладі (рис.1).

Характер впливу композиційних засобів залежить від характеристик комунікативних елементів та тієї структури, яку ці елементи утворюють. Отже, точність декодування змісту інформаційного повідомлення споживачами в наведеному прикладі напряму залежала від способу композиційної організації елементів. I зміна цього способу призводила до абсолютно відмінних змістових асоціацій. Отже, отримуємо нагоду стверджувати, що інформаційна структура - це результат впливу як безпосередньо образних властивостей самих комунікативних елементів, так і їх композиційної взаємодії, що в рекламно-графічній продукції бере на себе організуюче значення. Звідси, зміна способів композиційної взаємодії призводить до утворення іншої інформаційної структури, навіть за умови, що обидві структури вибудувані з однакових елементів.

У статті, присвяченій вивченню діалектичної єдності понять «форма» та «зміст»у графічному дизайні, Ганоцька (2011, с. 21) вказує: «....Асоціація - зв'язок, що виникає в процесі мислення, між елементами психіки, в результаті якої поява одного елементу, в певних умовах, викликає образ іншого, пов'язаного з ним; суб'єктивний образ об'єктивного зв'язку між елементами, предметами або явищами».

Доповнюючи дослідницю, маємо зазначити, що асоціації в графічному дизайні, саме i виникають у результаті об'єктивних композиційних зв'язків між елементами - різних рівнів 
ISSN 2410-1176 (Print) Вісник КНУКіМ. Серія Мистецтвознавство. Вип. 39. ISSN 2616-4183 (Online)

взаємодії графічних елементів між собою. Позбавлені чітко визначеного змістового наповнення, геометричні архетипи починають впливати на враження споживача та викликати в нього ті чи інші змістові асоціації саме внаслідок композиційної взаємодії між собою. Така взаємодія, як було зазначено вище, відіграє роль «змістового каркасу».

Спосіб кодування інформації на основі асоціативного варіювання властивостями геометричних примітивів або наближених до них форм в графічному дизайні поширений для створення знаків ідентифікації або інформації. Так, завдяки композиційній організації різноманітні за своїми семантичними характеристиками абстрактні, незображальні форми набувають чітко вираженого змісту та утворюють проектний образ. Таким чином формується логіка сприйняття знаків - образологіка, що дозволяє співвідносити схематизовані площинні зображення з об’єктами, процесами та явищами навколишнього світу.

Утворення знаків та варіювання потенціалом знакових форм у графічному дизайні обумовлене потребою в ефекті системності візуально-інформаційних структур, що найбільш активно виявляється у так званому фірмовому стилі. Сам принцип виникнення та утримання стилю базується на постійному збереженні потенціалу композиційного угрупування знакових форм. У цьому процесі навіть найменші відхилення від чітко визначених композиційних зв'язків між елементами призводять до утворення полістилістичних характеристик i варіювання асоціативними враженнями, які отримує споживач від їх споглядання. Надмірне захоплення спробами урізноманітнення таких візуальних структур найчастіше призводить до ефекту руйнування стильових характеристик. Такі інформаційні структури вже не володіють ознаками стильової єдності та не можуть претендувати на сприйняття змістової цілісності. Приклад руйнування візуально-стилістичних зв'язків на основі різних композиційних способів поєднання знаково-комунікативних елементів отримуємо 3 (рис. 2).

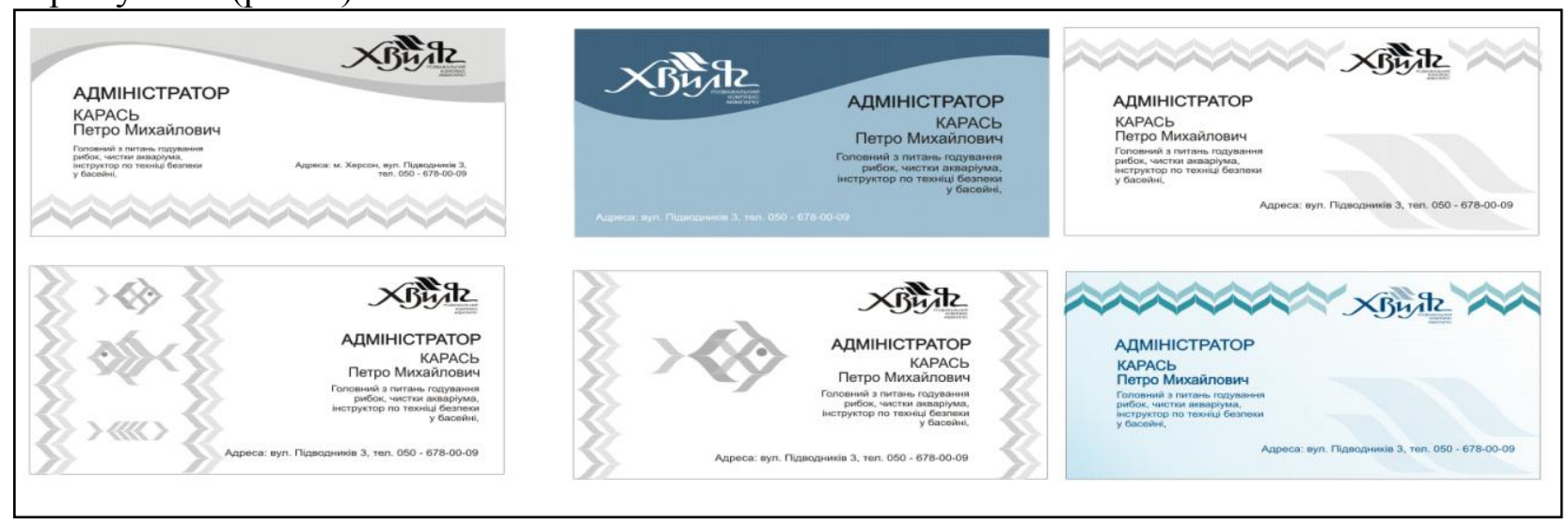

Рисунок 2. Руйнування стильової єдності внаслідок різного композиційного поєднання комунікативних елементів

Figure 2. Destruction of stylistic unity as a result of a different compositional combination of communicative elements

Наведені вище композиційні угрупування не дозволяють ідентифікувати носії як складові єдиного стилю. I це, незважаючи на те, що кожний 3 носіїв містить подібні конструктивні мікроелементи. Але різниця у способах композиційної взаємодії таких елементів саме і призводить до відчуття полістилізму та втрати цілісності. Сприйняттю наведених носіїв як складових єдиного стилю мало б сприяти утримання композиційних принципів близькості та схожості. Згідно принципу близькості стимули розташовані поруч, мають тенденцію сприйматися разом; згідно принципу схожості стимули, які схожі за розміром, контурами, кольором або формою, мають тенденцію сприйматися разом. Але різне просторове орієнтування знаково-комунікативних елементів на площині, вибіркове доповнення лекальними плямами вкупі з різними домінантними елементами призводять до руйнації означених принципів та, як результат, до полістилізму.

Але, утворення знаків передбачає й інші варіанти композиційних зв'язків, здатних ущільнювати інформацію та надавати іiі в концентрованому вигляді. У даному випадку 
маємо нагоду звернутись до літерно-алфавітних знаків та простежити способи посилення уваги до шрифтових повідомлень за рахунок їх поєднання зі знаковими формами. До таких способів композиційної організації належать так звані ефекти поєднання форми та контрформи, які подані на (рис. 3).

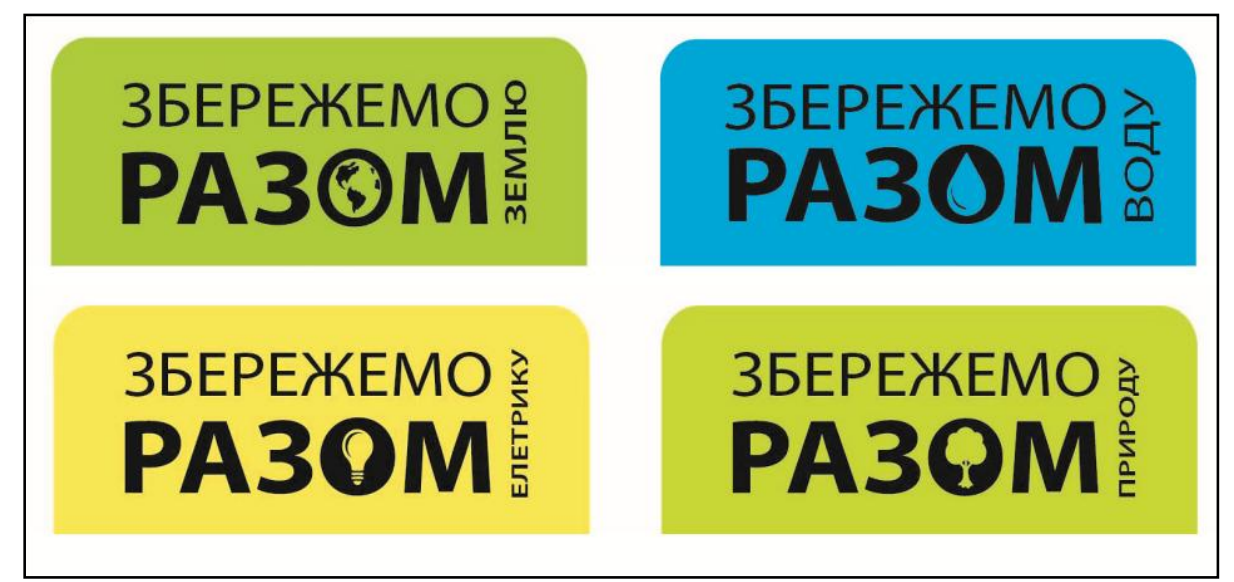

Рисунок 3. Композиційне поєднання форми та контрформи

Figure 3. Compositional combination of form and counter-form

Але в наведеному останньому прикладі вже немає можливості сверджувати, що проектувальник оперував виключно абстрактними, не зображувальними формами. Тут маємо справу 3 поєднанням форм літер шрифтів 3 формами об'єктів, котрі, хоча й були узагальненими та зведеними до схеми, однак мали чітко визначений зміст. Проте відмінною рисою наведеного композиційного угрупування є здатність до раціонального поєднання форм й підкреслення, в такий спосіб, змістового навантаження інформаційного повідомлення. Раціональне використання форм зображувального елементу та їх поєднання 3 формами літер, в даному випадку, сприяє забезпеченню композиційно-структурної єдності в організації інформаційного повідомлення.

Тут має місце композиційний принцип замкнутості, що відображує тенденцію вирішувати фігуру так, що вона набуває форми завершеного геометричного архетипу (в наведених прикладах таким архетипом є форма літери «О»).

3 наведених прикладів постає значущість композиційної структури, як цілісності, здатної набувати синергічних ознак й передавати інформацію значно більшу, ніж сукупність окремо взятих елементів. Тут знову бачимо прояви образологіки, що виявляється в посиленні дієвості впливу інформаційно-комунікативних елементів та їх піднесення до ступеня знакових форм.

Звернімось до висловлювання Ганноцької щодо співвідношення об'єктивного й суб'єктивного в художньому образі, що має витоки зі змістовності його форми: «Об’ єктивне - це уявлення абстрактного у своїй основі, що не залежить не від задуму автора, не від сприйняття глядачів. Суб'єктивність виражається в образі, який закладений автором у творі, і в образі, який отримує глядач. Разом з тим у дизайнерському творі водночас присутні об'єктивне як мета та суб'єктивне як результат» (Ганноцька 2011, с. 21). У такий спосіб об’єктивні властивості комунікативних елементів, що володіють значним потенціалом змістового декодування можуть набувати точності та однозначності сприйняття лише в разі утримання при їх побудові композиційних принципів та утворення, в такий спосіб на їх основі інформаційної структури, що володіє потенціалом для суб'єктивного сприйняття.

Розглянувши приклади, можемо зазначити, що закономірності поєднання образнологічного сприйняття значною мірою залежать від принципів гештальту, викладених Тафті та подібних до принципів композиційної організації комунікативних елементів: разом);

- принципу близькості (стимули, розташовані поруч, мають тенденцію сприйматися 
ISSN 2410-1176 (Print) Вісник КНУКіМ. Серія Мистецтвознавство. Вип. 39. ISSN 2616-4183 (Online)

- принципу схожість (стимули, схожі за розміром, контурами, кольором або формою, мають тенденцію сприйматися разом);

цілісності);

- принципу цілісності (об’єкти сприйняття мають тенденцію до спрощення й

- принципу замкнутості (відображує тенденцію завершувати фігуру так, що вона набуває повної форми);

- принципу суміжності (близькість стимулів у часі і просторі. Суміжність може зумовлювати сприйняття, коли співставлення відносно нейтральних в інформаційному плані образів викликає певні асоціації);

- принципу загальної зони (наше повсякденне сприйняття формується нарівні 3 навчанням і минулим досвідом, що зумовлюють думки і очікування, а також активно керують нашою інтерпретацією відчуттів).

У такий спосіб отримуємо підстави стверджувати, що в дизайнерській творчості саме варіювання закономірностями композиційної організації значної кількості абстрактних та символічних форм сприяють формуванню логічності та візуально-стилістичній єдності сприйняття образної інформації. Завдяки такій логічності формуються образні еквіваленти об'єктів, подій та явищ навколишнього світу, що активно споживаються сучасною масовою культурою та слугують альтернативою складним ілюзорно-реалістичним зображенням. Такі композиційні угрупування відкладаються і зберігаються в свідомості у вигляді образних одиниць інформації - іконів. Вплив цих образних еквівалентів $є$ подібним до впливу творів мистецтва.

Наукова новизна полягає у виявленні залежності змістового декодування відносно нейтральних комунікативних елементів від способів їх композиційної організації та у виявленні ролі композиції в формуванні візуально-стилістичної єдності носіїв фірмового стилю. Встановлено, що спосіб кодування інформації на основі асоціативного варіювання властивостями геометричних примітивів, або наближених до них форм призводить до формування логіки сприйняття знаків - образологіки, що дозволяє співвідносити схематизовані площинні зображення 3 об’єктами, процесами та явищами навколишнього світу. Закономірності такої образологіки співвіднесено з принципами гештальду, сформованими в психологічній галузі.

Висновок. Зміст візуальних повідомлень на основі знакових форм сприймається як відповідність цілісності образної побудови інформаційної структури до сутності візуально кодованих зображень. Дієвість механізмів «переробки» значної кількості образного, змістового та емоційного матеріалу в набір стереотипних уявлень, що активно продукуються і споживаються масовою культурою, забезпечується завдяки схематизації комунікативних елементів і дотримання умов композиційного представлення інформаційних кодів, дієвість впливу яких $є$ подібною до творів образотворчого мистецтва. Додержання принципів композиційної організації інформації, висвітлене у даній публікації, забезпечує єднання ідеї та форм їі графічного втілення.

\section{Список використаних джерел}

1. Ганоцька О. В. Діалектична єдність понять «форма» та «зміст» у графічному дизайні. Вісник Харківської державної академії дизайну $i$ мистецтв. Серія: Мистеитвознавство. Архітектура. Харків: ХДАДМ, 2011. №6. С. 19-22.

2. Михайленко В. Є., Яковлєв М. І. Основи композищії (геометричні аспекти художнього формотворення). Київ: Каравела, 2004. 304 с.

3. Тафти Э. Представление информации. Ридли [сайт]. URL:

http://readli.net/predstavlenie-informatsii/. (дата звернення: 15. 02. 2018)

4. Шевченко В. Я. Композииія плаката. Харків: Колорит, 2004. 123 с. : іл.

5. Bertin J. Semiology of graphics. Wisconsin : University of Wisconsin Press, 1983. 94 p. 


\section{References}

1. Bertin, J. (1983). Semiology of graphics. Wisconsin: University of Wisconsin Press.

2. Hanotska, O. (2011). Dialektychna yednist poniat «forma» ta «zmist»u hrafichnomu dyzaini [The dialectical unity of the concepts of "form" and "content" in graphic design]. Visnyk Kharkivskoi derzhavnoi akademii dyzainu i mystetstv. Seriia: Mystetstvoznavstvo. Arkhitektura, no.6, pp. 19-22.

3. Mykhailenko, V., Yakovliev, M. (2004). Osnovy kompozytsii (heometrychni aspekty khudozhnioho formotvorennia) [Fundamentals of composition (geometric aspects of artistic shaping)]. Kyiv: Karavela.

4. Tafty, E. 'Presentation of information'. Ridli, [online] Available at: $<$ http://readli.net/predstavlenie-informatsii/> [Accessed 15 February 2018].

5. Shevchenko, V. (2004). Kompozitsiia plakata [Poster composition]. Kharkiv: Koloryt.

(С) Божко Т. O., 2018

Стаття надійшла до редакиії: 31.08.2018

УДК 7.02:027.2

Вергунова Наталія Сергївна

кандидат мистецтвознавства,

Харківський національний університет міського господарства імені О. М. Бекетова, вул. Маршала Бажанова, 17, м. Харків, Украӥна https://orcid.org/0000-0002-8470-7956 n.vergunova@gmail.com

Вергунов Серсій Вімалійович кандидат мистецтвознавства,

Харківський національний університет міського господарства імені О. М. Бекетова, вул. Маршала Бажанова, 17, м. Харків, Україна, 61002 https://orcid.org/0000-0003-2603-9782 s.vergunov@gmail.com

\section{СКУЛЬПТУРА ЯК ПРОДУКТ ПРОМИСЛОВОГО ДИЗАЙНУ. ДОСВІД ЗАСТОСУВАННЯ В ПРОЕКТНІЙ ПРАКТИЦІ}

Мета дослідження полягає у виявленні та розгляді терміну «промислова скульптура» в діяльності промислового дизайнера. Методи дослідження полягають у застосуванні комплексу загальнонаукових методі (хронологічний та історико-порівняльний, метод термінологічного аналізу), що сприяв виявленню і розгляду об'єктів промислової скульптури в проектній дизайнерській практиці. Наукова новизна роботи полягає у позначенні певного відокремлення об'єктів промислової скульптури і їх розгляд у вгляді окремого сегмента в сучасній предметній культурі. Висновки. Положення, викладені в статті, свідчать про те, що скульптурні композиції, виконані в жанрі монументально-декоративної пластики можуть бути розглянуті як об'єкти промислового дизайну. Абстрагування від основного об'єкта скульптури - людини (результату), і зосередження на роботі скульптора (процесі) дозволяє виявити певну тотожність 3 процесом роботи промислового дизайнера, якого можна вважати скульптором промислової форми.

Об’ємна дизайнерська форма також будується згідно законів композиції, в тому ж реальному просторі і з урахуванням антропометричних особливостей споживачів, тому створювані дизайнером декоративні композиції формально-абстрактного характеру для 